\title{
Wpływ statusu społeczno-ekonomicznego na częstość występowania alergii
}

\section{The effects of socio-economic status on the prevalence of allergies}

\author{
Anna Stangret ${ }^{\boxplus}$, Martyna Żurawiecka² \\ ${ }^{1}$ Pomorski Uniwersytet Medyczny w Szczecinie, Katedra i Zakład Anatomii Prawidłowej i Klinicznej, al. Powstańców Wlkp. $72,70-111$ Szczecin \\ Pomeranian Medical University in Szczecin, Department of Human and Clinical Anatomy \\ ${ }^{2}$ Uniwersytet Jagielloński, Instytutu Zoologii i Badań Biomedycznych, Zakład Antropologii, ul. Gronostajowa 9, 30-387 Kraków \\ Jagiellonian University in Cracow, Institute of Zoology and Biomedical Research, Department of Anthropology \\ annastangret@wp.pl
}

\begin{abstract}
Introduction: More than $30 \%$ of the population suffer from allergic disorders, making it a civilization disease. Allergies are conditioned not only by genetic factors but also by environmental factors such as socio-economic status (SES).

The aim of study was to analyse the relationship batween the frequency of allergies and SES.

Materials and methods: 700 female students from the University of Łódź, Jagiellonian University and University of Physical Education in Cracow took part in the study. Students answered questions about the occurrence of allergies and specific allergens. Socio-economic status was defined by the place of residence before studies, number of siblings and education level of parents.
\end{abstract}

Results: In the studied group the occurrence of allergies was $29.71 \%$. Women living in urban areas before studies suffered from allergies twice as often as those who had lived in rural areas. Children with siblings had allergies less often than only children. A higher level of education of parents was connected with more frequent allergic reactions, but the difference was not statistically significant. Generally, people with a lower SES suffered less often from allergic reactions.

Conclusions: People with higher socio-economic status more often suffered from allergic reactions.

Keywords: allergy; socio-economic status.

rodziców. Trzech ostatnich zmiennych użyto do określenia statusu społeczno-ekonomicznego.

Wyniki: W badanej grupie częstość występowania alergii wynosiła 29,71\%. Badane mieszkające w mieście przed okresem studiów 2-krotnie częściej chorowały na alergie niż mieszkające na wsi. Jedynaczki częściej zapadały na choroby alergiczne niż osoby z rodzin wielodzietnych. Im wyższe było wykształcenia rodziców, tym częściej występowały alergie, jednak różnica nie była istotna statystycznie. Osoby o niższym SES rzadziej miały alergie.

Wnioski: Osoby o wyższym statusie społeczno-ekonomicznym częściej chorują na alergie.

Słowa kluczowe: alergia; status społeczno-ekonomiczny.

\section{WSTĘP}

Alergią nazywa się objawową reakcję organizmu na zadziałanie zwykle nieszkodliwego antygenu. Czynnik wywołujący uczulenie to alergen [1]. Na wystąpienie alergii mogą mieć wpływ czynniki zarówno biologiczne, jak i społeczno-ekonomiczne [2]. Układ immunologiczny jest główną linią obrony organizmu przed alergenami. Największą rolę w reakcjach alergicznych odgrywają: limfocyty, eozynofile oraz mastocyty, czyli komórki tuczne [3]. Przyczyną reakcji jest oddziaływanie antygenu z przeciwciałem lub działanie komórek T, które z powodu wcześniejszej ekspozycji na ten antygen zostały pobudzone [4]. Podwyższenie prawdopodobieństwa pojawienia się objawów choroby alergicznej mogą spowodować działające na organizm czynniki środowiskowe [5]. Z powodu różnorodności nasilenia i objawów zdiagnozowanie choroby jest bardzo trudne [6].

W ciągu ostatnich lat obserwuje się znaczny wzrost częstości występowania chorób alergicznych. Nie stanowią one bezpośredniego zagrożenia życia, jednak w znacznym stopniu obniżają jego komfort i jakość, co wpływa na utrudnienie codziennego funkcjonowania człowieka [7]. Obecnie alergia zaliczana 
jest do chorób cywilizacyjnych. U ok. 30-40\% populacji całego świata występuje przynajmniej jedna choroba alergiczna, natomiast w Polsce 40\% dzieci w wieku 6-7 lat wykazuje symptomy alergiczne. Liczba osób cierpiących na schorzenia alergiczne stale rośnie, a wg szacunków w 2020 r. będzie równać się liczbie osób zdrowych [8]. Badania statystyczne Światowej Organizacji Zdrowia pokazują, że setki milionów ludzi na całym świecie choruje na nieżyt nosa, a $300 \mathrm{mln}$ cierpi na astmę. W erze epidemii alergii badania pozwalające na dogłębne jej poznanie oraz udoskonalenie leczenia są niezwykle ważne. Dają szansę na poprawę funkcjonowania w społeczeństwie osób dotkniętych schorzeniami alergicznymi.

\section{Mechanizmy działania reakcji alergicznej}

W zależności od typu mechanizmy immunologiczne reakcji alergicznej różnią się od siebie [4]. Najbardziej powszechnym mechanizmem jest reakcja typu I, nazywana reakcją natychmiastową. Polega na wiązaniu alergenu do przeciwciał IgE, które odpłaszczają mastocyty. Wiązanie to generuje pobudzenie komórek tucznych, a ich zadaniem jest wydzielanie mediatorów, czyli substancji biologicznie czynnych, które wywołują objawy reakcji alergicznej, m.in. histaminy. Objawy wstępują zwłaszcza w tkankach, które zawierają dużą ilość mastocytów, takich jak: drogi oddechowe, śluzówka układu pokarmowego, spojówki i skóra [9] (tab. 1).

Typ II reakcji alergicznych może wystąpić w wielu tkankach organizmu. Do antygenów w tym typie zaliczamy m.in. leki, a przeciwciała należą przede wszystkim do grup IgA, IgM lub IgG.

Typ III jest procesem, który przebiega z udziałem kompleksów immunologicznych, czyli połączeń między przeciwciałami klasy IgG a antygenem. Kompleksy te aktywują białka układu dopełniacza. W tkankach, w których doszło do aktywacji, zastają również aktywowane płytki krwi i neutrofile, prowadzące do uszkodzenia tkanki. Czas wystąpienia reakcji to od 8 do nawet 72 godz. od wniknięcia antygenu, co powoduje, że alergie te są trudne do zdiagnozowania.

Typ IV to reakcja komórkowa. Ze względu na to, że występuje po 48-72 godz. od kontaktu z alergenem, nazywana jest reakcją opóźnioną. Zostają aktywowane limfocyty typu Th, które następnie wydzielają cytokiny, a te aktywują limfocyty cytotoksyczne niszczące tkanki organizmu z obecnym antygenem [9].

Same alergie można dodatkowo podzielić w zależności od układu, na jaki działają. Wyróżnia się 3 grupy: alergie kontaktowe, wziewne i pokarmowe. Mogą występować pojedynczo,

TABELA 1. Objawy powodowane przez mediatory [10]

\begin{tabular}{ll}
\hline Podrażnienie zakończeń nerwowych & Zaczerwienienie, świąd \\
\hline $\begin{array}{l}\text { Zwiększone wydzielanie śluzu przez } \\
\text { błony śluzowe }\end{array}$ & Katar sienny, łzawienie \\
\hline $\begin{array}{l}\text { Obrzęk oskrzeli (skurcz mięśni gładkich, } \\
\text { nadmierna sekrecja śluzu) }\end{array}$ & $\begin{array}{l}\text { Trudności w oddychaniu, } \\
\text { świszczący oddech }\end{array}$ \\
\hline Rozkurcz naczyń krwionośnych & Zaczerwienienie \\
\hline $\begin{array}{l}\text { Wzmożona przenikalność naczyń } \\
\text { krwionośnych }\end{array}$ & $\begin{array}{l}\text { Bąbel pokrzywkowy, } \\
\text { obrzęk }\end{array}$ \\
\hline
\end{tabular}

jak i równocześnie, jednak mechanizm działania znacząco się różni [11].

\section{Hipoteza higieny}

Pierwszy raz hipoteza ukazała się w Brithish Medical Journal w 1989 r. i została przedstawiona przez Davida Strachana. Obecnie jest jedną z najpopularniejszych hipotez, które tłumaczą wpływ czynników środowiskowych na częstość występowania alergii [12].

Według licznych badań istnieją istotne różnice w stanie zdrowia pomiędzy grupami o odmiennym statusie społeczno-ekonomicznym (SES). Pierwszym i zarazem najistotniejszym czynnikiem, który kształtuje zdrowie dzieci, jest środowisko rodzinne. Zachowania szkodliwe dla zdrowia dziecka, takie jak np. palenie ty toniu w trakcie ciąży lub podczas rozwoju dziecka, częściej występują u rodzin o niższym statusie społeczno-ekonomicznym. Wraz z wiekiem matki wzrasta umiejętność wychowania dzieci. Obecnie kobiety o wyższym SES, później niż kobiety o niższym statusie decydują się na potomstwo [13].

Zasadniczo u osób o wysokim statusie społeczno-ekonomicznym obserwuje się mniejszą zachorowalność, a co za tym idzie - lepszy stan zdrowia niż u osób o niskim statusie. Wynika to przede wszystkim z większej wiedzy na temat zachowań prozdrowotnych. Nie bez znaczenia są również możliwości finansowe, co wiąże się z lepszym dostępem do opieki medycznej. Status społeczno-ekonomiczny ma również wpływ na warunki mieszkaniowe, środowisko pracy, sposób żywienia oraz aktywność fizyczną [14].

Alergia, często nazywana chorobą dobrobytu, należy do nielicznej grupy chorób, które częściej występują u osób o wyższym SES. Wzrost zachorowalności jest widoczny nie tylko w krajach o wyższym statusie, ale również można obserwować różnice pomiędzy grupami o różnych statusach w obrębie jednego kraju. Status społeczno-ekonomiczny jest skorelowany ze stylem życia, jednak wyższy status niekoniecznie jest korzystny dla osób chorujących na alergie. Charakterystyczny dla niektórych grup o wysokim SES styl życia (spędzanie czasu w zamkniętych pomieszczeniach, ograniczone przebywanie na świeżym powietrzu czy klimatyzacja) może wzmacniać incydenty alergiczne. Dodatkowo w grupach tych występuje wyraźnie większe spożycie wysoko przetworzonej żywności. Jedna z hipotez zakłada, że częstsza zapadalność na choroby infekcyjne zapobiega występowaniu alergii. U dzieci, które mają częstszy kontakt z rówieśnikami, a przez to częściej „łapią” infekcję, rzadziej obserwuje się atopię [15].

Celem niniejszej pracy była weryfikacja powyższej hipotezy oraz zbadanie, czy wyższy status społeczno-ekonomiczny wpływa na częstość występowania chorób alergicznych u studentek.

\section{MATERIAtY I METODY}

Badania przekrojowe obejmowały łącznie 700 studentek Uniwersytetu Łódzkiego, Uniwersytetu Jagiellońskiego oraz Akademii Wychowania Fizycznego w Krakowie. Grupę młodych kobiet zapytano, czy badania medyczne wykazały u nich 
występowanie alergii, a jeśli tak, to na jakie alergeny są uczulone. Kwestionariusz obejmował również pytania dotyczące miejsca zamieszkania przed okresem studiów, wykształcenia matki i ojca, a także liczby rodzeństwa. Odpowiedzi pozwoliły określić status społeczno-ekonomiczny badanej grupy. Zmienne analizowane w prezentowanej pracy są czynnikami modyfikującymi poziom rozwoju ontogenetycznego $[16,17]$ i zostały zakwalifikowane do poniższych kategorii:

1. Urbanizacja (wg Wykazu urzędowego nazw w Polsce):
a) wsie,
b) miasta do 100 tys. mieszkańców,
c) miasta powyżej 100 tys. mieszkańców.

2. Liczba dzieci w rodzinie:
a) czworo i więcej
b) troje,
c) dwoje
d) jedno.

3. Wykształcenie rodziców:
a) podstawowe,
b) zawodowe,
c) średnie,
d) wyższe.

Na podstawie powyższych zmiennych badane podzielono na 3 grupy o niskim, przeciętnym i wysokim statusie społeczno-ekonomicznym.

Analizy statyczne wykonano w programie Statistica 10. Wykorzystano metody statystyki opisowej (średnia, mediana, odchylenie standardowe, rozkład frakcji). Dla określenia istotności różnic pomiędzy zmiennymi kategorycznymi zastosowano test niezależności $\chi^{2}$. Istotność różnic pod względem cech ciągłych określano za pomocą testu t-Studenta. Przyjęto poziom istotności $\mathrm{p}<0,05$.

\section{WYNIKI}

Występowanie alergii zanotowano u 208 (29,71\%) studentek. Najczęstszymi deklarowanymi alergenami były: sierść zwierzęca, pyłki roślinne, kurz, roztocza oraz leki. Wyniki badanej zależności pomiędzy występowaniem alergii a statusem społeczno-ekonomicznym przedstawiono w tabelach 2-5.

W tabeli 2 wraz ze wzrostem SES zaobserwowano wzrost częstości występowania chorób alergicznych. U badanych, które przed studiami mieszkały na wsi, alergie występowały 2-krotnie rzadziej niż u badanych, które przed studiami mieszkały w mieście. Różnica jest istotna statystycznie. Widoczny jest również wzrost częstości zachorowalności na alergie wraz ze wzrostem wykształcenia rodziców (tab. 3). Zarówno w przypadku ojca, jak i matki różnice były jednak nieistotne statystycznie. Jedynaczki częściej chorują na alergie niż osoby z rodzin wielodzietnych (tab. 4).

W celu zweryfikowania hipotezy utworzono kompleksowy wskaźnik statusu. W poszczególnych zmiennych przypisano wartości liczbowe dla każdej z kategorii. Dla miejsca zamieszkania: 1 - wieś, 2 - miasteczko, 3 - miasto. Dla wykształcenia rodziców: 1 - zawodowe, 2 - średnie, 3 - wyższe. Dla liczby
TABELA 2. Występowanie alergii w zależności od miejsca zamieszkania

\begin{tabular}{|c|c|c|c|c|c|c|}
\hline \multicolumn{2}{|c|}{ Czynnik } & \multicolumn{2}{|c|}{$\begin{array}{l}\text { Osoby bez } \\
\text { alergii }\end{array}$} & \multicolumn{2}{|c|}{$\begin{array}{c}\text { Osoby } \\
\text { z alergią }\end{array}$} & \multirow{2}{*}{$\begin{array}{l}\text { Wartość } \\
\text { testu } X^{2}\end{array}$} \\
\hline & & $\mathrm{n}$ & $\%$ & $n$ & $\%$ & \\
\hline \multirow{3}{*}{$\begin{array}{l}\text { Miejsce za- } \\
\text { mieszkania }\end{array}$} & wieś & 186 & 80,52 & 45 & 19,48 & \multirow{3}{*}{$\begin{array}{l}x^{2}=25,57 \\
d f=2 \\
p=0,000\end{array}$} \\
\hline & miasteczko & 195 & 73,86 & 69 & 26,14 & \\
\hline & miasto & 140 & 59,83 & 94 & 40,17 & \\
\hline
\end{tabular}

TABELA 3. Występowanie alergii w zależności od wyksztatcenia rodziców

\begin{tabular}{|c|c|c|c|c|c|c|}
\hline \multicolumn{2}{|c|}{ Czynnik } & \multicolumn{2}{|c|}{$\begin{array}{l}\text { Osoby bez } \\
\text { alergii }\end{array}$} & \multicolumn{2}{|c|}{$\begin{array}{c}\text { Osoby } \\
\text { z alergią }\end{array}$} & \multirow{2}{*}{$\begin{array}{l}\text { Wartość } \\
\text { testu } \chi^{2}\end{array}$} \\
\hline & & $\mathbf{n}$ & $\%$ & $\mathbf{n}$ & $\%$ & \\
\hline \multirow{3}{*}{$\begin{array}{l}\text { Wykształce- } \\
\text { nie matki }\end{array}$} & zawodowe & 89 & 73,55 & 32 & 26,45 & \multirow{3}{*}{$\begin{array}{l}X^{2}=1,73 \\
d f=2 \\
p=0,4129\end{array}$} \\
\hline & średnie & 197 & 73,51 & 71 & 26,49 & \\
\hline & wyższe & 235 & 69,12 & 105 & 30,88 & \\
\hline \multirow{3}{*}{$\begin{array}{l}\text { Wykształce- } \\
\text { nie ojca }\end{array}$} & zawodowe & 198 & 72,53 & 75 & 27,47 & \multirow{3}{*}{$\begin{array}{l}X^{2}=0,81 \\
d f=2 \\
p=0,6684\end{array}$} \\
\hline & średnie & 163 & 72,44 & 62 & 27,56 & \\
\hline & wyższe & 160 & 69,26 & 71 & 30,74 & \\
\hline
\end{tabular}

TABELA 4. Występowanie alergii w zależności od ilości posiadanego rodzeństwa

\begin{tabular}{|c|c|c|c|c|c|c|}
\hline \multirow[t]{2}{*}{ Czynnik } & & \multicolumn{2}{|c|}{$\begin{array}{l}\text { Osoby bez } \\
\text { alergii }\end{array}$} & \multicolumn{2}{|c|}{$\begin{array}{c}\text { Osoby } \\
\text { z alergią }\end{array}$} & \multirow{2}{*}{$\begin{array}{l}\text { Wartość } \\
\text { testu } X^{2}\end{array}$} \\
\hline & & $n$ & $\%$ & $\mathbf{n}$ & $\%$ & \\
\hline \multirow{4}{*}{ Rodzeństwo } & 4 & 65 & 80,25 & 16 & 19,75 & \multirow{4}{*}{$\begin{array}{c}x^{2}=8,91 \\
d f=2 \\
p=0,0306\end{array}$} \\
\hline & 3 & 140 & 75,68 & 45 & 24,32 & \\
\hline & 2 & 239 & 70,09 & 102 & 29,91 & \\
\hline & 1 & 78 & 63,41 & 45 & 36,59 & \\
\hline
\end{tabular}

TABELA 5. Występowanie alergii w zależności od statusu społeczno-ekonomicznego

\begin{tabular}{|c|c|c|c|c|c|c|}
\hline \multirow{2}{*}{\multicolumn{2}{|c|}{ Czynnik }} & \multicolumn{2}{|c|}{$\begin{array}{c}\text { Osoby bez } \\
\text { alergii }\end{array}$} & \multicolumn{2}{|c|}{$\begin{array}{c}\text { Osoby } \\
\text { z alergią }\end{array}$} & \multirow{2}{*}{$\begin{array}{l}\text { Wartość } \\
\text { testu } X^{2}\end{array}$} \\
\hline & & $\mathrm{n}$ & $\%$ & $n$ & $\%$ & \\
\hline \multirow{3}{*}{$\begin{array}{l}\text { Status } \\
\text { społeczno- } \\
\text {-ekonomiczny }\end{array}$} & $\begin{array}{l}\text { poniżej } \\
\text { przeciętnej }\end{array}$ & 164 & 78,1 & 46 & 21,9 & \multirow{3}{*}{$\begin{array}{c}x^{2}=12,21 \\
d f=2 \\
p=0,0022\end{array}$} \\
\hline & przeciętny & 246 & 72,35 & 94 & 27,65 & \\
\hline & $\begin{array}{l}\text { powyżej } \\
\text { przeciętnej }\end{array}$ & 112 & 62,22 & 68 & 37,78 & \\
\hline
\end{tabular}

rodzeństwa: 1 - troje i więcej, 2 - dwoje, 3 - jedno, 4 - jedynak. Po zsumowaniu kategorii dla każdego z czynników, badani zostali podzieleni na 3 grupy. Studentki, które uzyskały sumę niższą od wartości 25 centyla, zostały zaliczone do grupy o niskim statusie. Jeżeli suma mieściła się między 25-75 centylem, osoby były zaliczane do grupy o przeciętnym statusie. Przy sumie wyższej niż 75 centyl osoby kwalifikowano do grupy o wysokim statusie.

Sprawdzono, czy różnice pomiędzy poszczególnymi grupami o różnym statusie społeczo-ekonomicznym a częstością występowania alergii są istotne statystycznie. Za pomocą testu $\chi^{2}$ wykazano istotność statystyczną dla różnic w badanych grupach (tab. 5). Stwierdzono, że alergie występują znacznie częściej u osób o wysokim statusie społeczno-ekonomicznym. 


\section{DYSKUSJA I WNIOSKI}

Alergia jest chorobą wielogenową, zatem w przypadku, gdy występuje ona u jednego lub u obojga rodziców, prawdopodobieństwo ujawnienia się choroby u dziecka jest wyższe niż w przypadku rodziców zdrowych $[15,18]$. Jednak dziecko dwojga alergików może być zdrowe, gdyż wystąpienie alergii wzmacniane jest działaniem czynników środowiskowych, tj.: zanieczyszczeniem (wody, powietrza), ekspozycją na dym tytoniowy, żywnością przepełnioną syntetycznymi składnikami, utrwalaczami i sztucznymi barwnikami oraz pośrednio czynnikami związanymi ze stylem i warunkami życia, jak status ekonomiczno-społeczny, aktywność fizyczna czy sposób żywienia [2]. Czynnikiem będącym najczęstszym obiektem badań wydaje się status społeczno-ekonomiczny. Składa się na niego wiele czynników: miejsce zamieszkania (miasto, wieś), wykształcenie rodziców czy wielkość rodziny. Zaobserwowano dużą jego zależność z występowaniem alergii [19, 20, 21].

Zróżnicowanie w stopniu występowania alergii między miastem a wsią zostało zarejestrowane w kilku pracach naukowych $[22,23]$. Prezentowane badania ankietowe potwierdziły tę zależność i wykazały, że na częstość występowania alergii istotny wpływ ma miejsce zamieszkania. Osoby zamieszkujące wieś przed okresem studiów były dotknięte alergią w 19,48\%, natomiast zamieszkujące miasto w 40,17\%, co świadczy o 2-krotnie wyższym odsetku alergików w mieście niż na wsi. Miejsce zamieszkania także ma swój wpływ na występowanie alergii. Zakłada się, że w mniejszych wioskach dostęp do opieki lekarskiej jest mniejszy i trudniejszy, a świadomość społeczeństwa na temat chorób alergicznych niższa. Przyczyniać się to może do częstego braku odpowiedniej diagnozy. Schorzenie alergiczne mylone może być ze zwykłym przeziębieniem. Jest to kolejny czynnik mogący wpłynąć na różnice w występowaniu alergii w miastach i na wsiach. Inne wyjaśnienie różnic w częstości występowania alergii pomiędzy dziećmi z miast i ze wsi to ekspozycja na alergeny. Dzieci na wsiach, ze względu na obecność w ich sąsiedztwie różnorodnych roślin i zwierząt od wczesnego dzieciństwa stykają się z dużą ilością alergenów [24].

Kolejnym czynnikiem składającym się na wysokość statusu społeczno-ekonomicznego jest poziom wykształcenia rodziców. Wyższe wykształcenie niesie za sobą lepszą pracę, co z kolei gwarantuje wyższe zarobki i życie na wyższym poziomie materialnym. Standard życia jest wyższy, a to - zgodnie z hipotezą higieny - może być przyczyną częstszego występowania alergii [25]. W prezentowanych badaniach stopień wykształcenia rodziców nie miał wpływu na częstość występowania alergii u dzieci. Dziewczęta, których rodzice posiadali wyższe wykształcenie, częściej cierpiały na choroby alergiczne, jednak różnica była statystycznie nieistotna.

Analiza otrzymanych wyników ujawniła także istotność wpływu liczby rodzeństwa na częstość występowania alergii. Choroby alergiczne rzadziej dotykały osób pochodzących z rodzin wielodzietnych. Analogicznie do wyników innych autorów, znacznie częściej alergie zanotowano u jedynaczek niż u tych, które posiadają rodzeństwo. Można to wytłumaczyć faktem, że dzieci posiadające rodzeństwo są bardziej narażone na infekcje. Podkreśla się szczególnie narażenie na infekcje w pierwszych 6 miesiącach życia $[12,26]$. Wiadomo, że w rodzinie z większą liczbą dzieci ekspozycja na alergeny jest większa, dlatego też obserwuje się rzadsze występowanie alergii w rodzinach wielodzietnych. Tłumaczyć to może hipoteza higieny wysnuta przez Strachana w 2000 r. Sadził on, iż infekcje przebyte $w$ dzieciństwie, przeniesione poprzez niehigieniczny kontakt ze starszym rodzeństwem lub z matką, która także miała kontakt z tym rodzeństwem, może chronić przed wystąpieniem chorób alergicznych lub przynajmniej zmniejszyć ryzyko ich wystąpienia. Można sądzić, iż niższa częstość występowania tych chorób na terenach wiejskich spowodowana jest faktem, iż na wsiach częściej niż w miastach występują rodziny wielodzietne [24].

Generalnie osoby z wyższym statusem społeczno-ekonomicznym częściej chorują na alergie. W wykonanym badaniu w grupie osób o statusie społeczno-ekonomicznym niższym niż przeciętny alergię miało 21,9\%, natomiast wśród osób o statusie wyższym niż przeciętny - 37,78\%. Alergia zwana jest chorobą dobrobytu. Wzrost częstotliwości występowania alergii obserwowany jest w populacjach żyjących na poziomie wyższym od przeciętnego [7, 12, 21, 27]. Istotną rolę w tym zjawisku odgrywa „westernizacja” społeczeństwa [28]. Większość czynników środowiskowych mających wpływ na występowanie alergii jest związana z postępem cywilizacyjnym: zanieczyszczeniem powietrza i wody, dodawaniem do żywności środków konserwujących oraz sztucznych barwników i innych dodatków, narażeniem na dym tytoniowy, masowym stosowaniem antybiotyków. Ważną rolę przypisuje się też czynnikom związanym ze stylem życia, takim, jak: mała aktywność fizyczna, częste przebywanie w pomieszczeniach zamkniętych o szczelnych oknach lub klimatyzacji, dieta oparta na wysoko przetworzonej żywności $[8,12]$. Otrzymane w ramach prezentowanych badań wyniki potwierdziły słuszność hipotezy higieny i wskazały, że występowaniu alergii sprzyja wysoki status społeczno-ekonomiczny. Niektórzy naukowcy uważają, że do wyższej częstość alergii u ludzi o wyższym SES przyczynić się może także fakt, iż takie osoby stać na prywatną opiekę medyczną, niejednokrotnie całodobową. Taki wykwalifikowany personel potrafi zdiagnozować chorobę alergiczną. Badania Marmota i wsp. pokazały jednak, że status społeczno-ekonomiczny sprzyja występowaniu, a nie tylko wykrywaniu alergii. Autorzy przebadali bardzo dużą grupę poborowych, u każdego z nich wykonując testy alergiczne. Alergie istotnie częściej wykrywali u mężczyzn z rodzin o wysokim statusie [25].

\section{PIŚMIENNICTWO}

1. Rajan TV. The Gell-Coombs classification of hypersensitivity reactions: a reinterpretation. Trends Immunol 2003;24(7):376-9.

2. Von Mutius E. The environmental predictors of allergic disease. J Allergy Clin Immunol 2000;105(1):9-19.

3. Wahl R, Silva Rodriques A. Alergologia w praktyce. Bielsko-Biała: Alfa Medica Press; 2007.

4. Janeway ChA Jr., Travers P, Wolpart M, Shlomchik MJ. Immunobiology: the immune system in health and disease. New York: Garland Science; 2001. 
5. Wickman M, Melen E, Berglind N, Lennart Nordvall S, Almqvist C, Kull I, et al. Strategies for preventing wheezing and asthma in small children. Allergy 2003;58:742-7.

6. Jackson M. Allergy: the making of modern plague. Clin Exp Allergy 2001;31:1665-71.

7. Gold DR. Allergy: the price paid for longe vity and social wealth. J Allergy Clin Immunol 2006;117(1):148-50.

8. Smoliński B, Fronczak A, Kuna P, Akdis CA, Anto JM, Białoszewski AZ, et al. Prevention and control of childhood asthma and allergy in the EU from public health point of view: Polish Presidency of European Union. Eur J Allergy Clin Immunol 2012;67:726-31.

9. Jabłońska S, Majewski S. Choroby skóry i choroby przenoszone drogą płciowa. Warszawa: Wyd. Lek. PZWL; 2010.

10. Obtułowicz K. Alergologia praktyczna. Warszawa: Wyd. Lek. PZWL; 2001.

11. Chmielewska-Szewczyk D. Alergia u dzieci. Warszawa: Państwowy Zakład Wydawnictw Lekarskich; 1983.

12. Strachan DP. Family size, infection and atopy: the first decade of the "hygiene hypothesis". Thorax 2000;55 Suppl 1:S2-10.

13. Ruijsbroek A, Wijga AH, Kerkhof M, Koppelman GH, Smit HA, Droomers $\mathrm{M}$. The development of socio-economic health differences in childhood: results of longitudinal PIAMA birth cohort. BMC Public Health 2011;11:225-35.

14. Pawlińska-Chmara R, Wronka I. The influence of allergic disorders on physical development. Eur J Med Res 2009;14(4):187-91.

15. Pawlińska-Chmara R, Wronka I, Muc M. Prevalence and correlates of allergic diseases among children. J Physiology Pharmacol 2008;59(6):549-56.

16. Malinowski A. Wstęp do antropologii i ekologii człowieka. 2nd ed. Łódź: Wydawnictwo Uniwersytetu Łódzkiego; 1999.

17. Łaska-Mierzejewska T. Antropologia w sporcie i wychowaniu fizycznym. Warszawa: Centralny Ośrodek Sportu; 1999.
18. Seinke JW, Rich SS, Boris L. Genetics of allergic disease. J Allergy Clin Immunol 2008;121:384-7.

19. Ernst P. Socioeconomic status and childhood atopy. Can Respir J 1996;3(1):53-7.

20. Forastiere F, Agabiti N, Corbo GM. Socioeconomic status, number of siblings and respiratory infections in early life as determinants of atopy in children. Epidemiology 1997;8:566-70.

21. Levis SA, Weiss ST, Platts-Mills TAE, Syring M, Gold DR. Association of specific allergen sensitization with socioeconomic factors an allergic disease in the population of Boston women. J Allergy Clin Immunol 2001;107(4):615-22.

22. Sozanska B, MacNeill SJ, Kajderowicz-Kowalik M, Danielewicz H, Wheatley M, Newman Taylor AJ, et al. Atopy and asthma in rural Poland: A paradigm for the emergence of childhood respiratory allergies in Europe. Allergy 2007;62:394-400.

23. Riedler J, Eder W, Oberfeld G, Schreuer M. Austrian children living on a farm have less hay fever, asthma and allergic sensitization. Clin Exp Allergy 2000;30:194-200.

24. Krotkiewicz M, Madaliński K. Im wyższy poziom higieny, tym więcej alergii - paradoks naszych czasów. Alerg Astma Immun 2000;5(1): $1-6$.

25. Marmot MG, Kogevinas M, Elston MA. Social/economic status and disease. Annu Rev Public Health 1987;8:111-35.

26. Okada H, Kuhn C, Feillet H, Bach JF. The 'hygiene hypothesis' for autoimmune and allergic diseases: an update. Clin Exp Immunol 2010;160:1-9.

27. Arshad SH, Hide DW. Effect of environmental factors on the development of allergic disorders in infancy. J Allergy Clin Immunol 1992;90:235-41.

28. Migliore E, Pearce N, Bugiani M, Galletti G, Biggeri A, Bisanti L, et al. Collaborative group prevalence of respiratory symptoms in migrant children to Italy the results of SIDRIA-2 study. Allergy 2007;62:293-300. 